\title{
MENINGKATAN KETERAMPILAN MENGAJAR GURU DALAM MEMBIMBING DISKUSI KELOMPOK KECIL MELALUI PENDEKATAN KOLABORATIF
}

\author{
Slamed \\ Pengawas SMA Dinas Pendidikan dan Kebudayaan Propinsi Kalimantan Barat \\ Email: slamed_12@yahoo.com
}

\begin{abstract}
The purpose of this study was to determine: 1). How is the process of implementing a collaborative approach in an effort to improve teacher teaching skills in guiding small group discussions; 2). Whether a collaborative approach can improve teacher teaching skills in guiding small group discussions. This type of research is School Action Research. The results of the study concluded that: 1) The process of implementing a collaborative approach was carried out in 6 stages, namely: initial conversation, observation, analysis, final conversation, final analysis and discussion. 2) A collaborative approach can improve teacher teaching skills in guiding small group discussions at SMAN 2 Sintang, SMAN 1 Sepauk and SMA Sinar Kasih Sintang. This is indicated by the average value that has increased from cycle I to cycle II. The average value of teacher teaching skills in guiding SMAN small group discussions 2 Sintang increased by 17\%, at SMAN 1 Sepauk increased by $16 \%$ and at SMA Sinar Kasih Sintang increased by $15 \%$.
\end{abstract}

Keywords: Group Discussion, Teacher Teaching Skills, Collaborative Approach.

\begin{abstract}
Abstrak
Tujuan Penelitian ini adalah untuk mengetahui: 1). Bagaimana proses pelaksanaan pendekatan kolaboratif dalam upaya meningkatkan keterampilan mengajar guru dalam membimbing diskusi kelompok kecil; 2). Apakah pendekatan kolaboratif dapat meningkatkan keterampilan mengajar guru dalam membimbing diskusi kelompok kecil. Jenis penelitian ini adalah Penelitian Tindakan Sekolah. Hasil penelitian menyimpulkan bahwa: 1) Proses pelaksanaan pendekatan kolaboratif dilakukan melalui 6 tahap yaitu: percakapan awal, observasi, analisis, percakapan akhir, analisis akhir dan diskusi. 2) Pendekatan kolaboratif dapat meningkatkan keterampilan mengajar guru dalam membimbing diskusi kelompok kecil di SMAN. 2 Sintang, SMAN. 1 Sepauk dan SMA. Sinar Kasih Sintang. Hal ini ditunjukkan dengan nilai rata-rata yang mengalami peningkatan dari siklus I ke siklus II. Nilai rata-rata keterampilan mengajar guru dalam membimbing diskusi kelompok kecil SMAN. 2 Sintang terjadi peningkatan sebesar 17\%, di SMAN. 1 Sepauk terjadi peningkatan sebesar 16\% dan di SMA Sinar Kasih Sintang terjadi peningkatan sebesar $15 \%$.
\end{abstract}

\section{Kata Kunci: Diskusi Kelompok, Keterampilan Mengajar Guru, Pendekatan Kolaboratif.}

\section{PENDAHULUAN}

Agar seorang guru profesional dalam melaksanakan tugasnya maka sudah selayaknya seorang guru memiliki kompetensi seperti yang telah dipersyaratkan dalam aturan yang ada. Menurut Permendiknas Nomor 16 Tahun 2007 tentang Standar Kualifikasi Akademik dan Kompetensi Guru disebutkan salah satu kompetensi yang harus dimiliki guru adalah kompetensi pedagogik. Dalam UU Nomor 19 Tahun 2005 tentang Standar Nasional Pendidikan pada pasal 28 ayat 3 butir (a) disebutkan kompetensi pedagogik adalah kemampuan mengelola pembelajaran peserta didik yang meliputi pemahaman terhadap peserta didik, perancangan dan pelaksanaan pembelajaran, evaluasi hasil belajar dan pengembangan peserta didik untuk mengaktualisasikan berbagai potensi yang dimilikinya.

Pelaksanaan pembelajaran akan dapat mengembangkan potensi yang dimiliki oleh peserta didik dalam mengaktualisasikan berbagai kemampuannya jika seorang guru memiliki keterampilan mengajar. Menurut Kusnadi (2008:45) keterampilan mengajar adalah kemampuan yang dimiliki seorang guru dalam melakukan pengajaran kepada siswanya sehingga siswa dapat memahami materi pelajaran yang diajarkan. 
Ada berbagai keterampilan mengajar yang harus dikuasai oleh seorang guru agar pembelajaran yang dilaksankannya berkualitas. Menurut Turney dalam E. Mulyasa (2011:69) ada 8 keterampilan mengajar yang sangat berperan dan menentukan kualitas pembelajaran, yaitu keterampilan bertanya, memberi penguatan, mengadakan variasi, menjelaskan, membuka dan menutup pelajaran, membimbing diskusi kelompok kecil, mengelola kelas serta mengajar kelompok kecil dan perorangan.

Keterampilan membimbing diskusi kelompok kecil diperlukan agar terlaksana proses pembelajaran serta dapat memotivasi peserta didik untuk berpartisipasi aktif dalam kegiatan belajar mengajar. Bimbingan yang diberikan oleh guru dalam kegiatan pembelajaran salah satunya adalah melalui metode diskusi kelompok, menurut E. Mulyasa (2011:89) diskusi kelompok adalah suatu proses yang teratur dan melibatkan sekelompok orang dalam interaksi tatap muka untuk mengambil kesimpulan dan memecahkan masalah. Sejalan hal tersebut menurut Rusman (2014:203) dalam pembelajaran kelompok akan tercipta sebuah interaksi yang lebih luas, yaitu interaksi dan komunikasi yang dilakukan antara guru dengan siswa, siswa dengan siswa, dan siswa dengan guru.

Kegiatan pembelajaran dengan menggunakan metode diskusi kelompok akan dapat melatih peserta didik agar dapat berkembang secara maksimal sesuai dengan kemampuan masingmasing karena dapat menginspirasi mereka untuk belajar lebih aktif, didalam Permendikbud Nomor 22 Tahun 2016 tentang Standar Proses Pendidikan Dasar dan Menengah disebutkan proses pembelajaran pada satuan pendidikan diselenggarakan secara interaktif, inspiratif, menyenangkan, menantang, memotivasi peserta didik untuk berpartisipasi aktif, serta memberikan ruang yang cukup bagi prakarsa, kreativitas, dan kemandirian sesuai dengan bakat, minat, dan perkembangan fisik serta psikologis peserta didik.

Berdasarkan hasil pembinaan guru oleh pengawas sekolah melalui supervisi kunjungan kelas yang telah dilakukan pada semester 1 tahun pelajaran 2017/2018 terhadap 14 orang guru di 7 sekolah binaan yang merupakan tanggung jawab penulis selaku pengawas pembina maka diperoleh data-data sebagai berikut:

Tabel 1. Hasil Supervisi Kunjungan Kelas

\begin{tabular}{ccc}
\hline No & Nama Guru (Inisial) & Nilai \\
\hline 1. & FRRL & 74 \\
\hline 2. & RD & 64 \\
\hline 3. & SW & 62 \\
\hline 4. & NL & 61 \\
\hline 5. & SM & 82 \\
\hline 6. & WE & 72 \\
\hline
\end{tabular}

\begin{tabular}{ccc}
\hline 7. & LS & 74 \\
\hline 8. & SN & 76 \\
\hline 9. & SI & 62 \\
\hline 10. & MM & 83 \\
\hline 11. & EK & 68 \\
\hline 12. & DS & 62 \\
\hline 13. & SB & 71 \\
\hline 14. & HE & 64 \\
\hline
\end{tabular}

Dari 14 orang guru yang sudah di supervisi 7 orang guru melaksanakan pembelajaran dengan menggunakan metode diskusi kelompok yaitu guru yang berinisial RD, SM, NL, SN, SI, MM, SB sedangkan guru yang lain menggunakan metode ceramah. Dari hasil supervisi terhadap guru-guru yang melaksanakan pembelajaran dengan metode diskusi kelompok didapatkan informasi yang cukup bervariasi.

Pengamatan terhadap guru yang melaksanakan metode diskusi kelompok dilakukan di SMA Sinar Kasih Sintang terhadap guru RD pada tanggal 15 September 2017 pada jam pelajaran 3-4 di kelas 12 IPA. Pada saat berlangsungnya kegiatan belajar mengajar guru kurang memberikan kesempatan pada peserta didik untuk menemukan konsep materi sehingga guru lebih dominan dalam pembelajaran, sedangkan dalam mengerjakan tugas masih nampak sebagian peserta didik yang masih kurang aktif dalam menyelesaikan tugas yang diberikan guru.

Adanya permasalahan dalam membimbing diskusi kelompok oleh guru terhadap peserta didik juga nampak ketika dilakukan supervisi kunjungan kelas di SMAN. 2 Sintang terhadap guru SI pada tanggal 23 Oktober 2017 jam pelajaran 4-5 di kelas X IIS 2. Dari hasil pengamatan didapatkan fakta bahwa guru sangat dominan dalam pembelajaran yang berlangsung sehingga diskusi kelompok yang diharapkan berjalan sesuai rencana tidak dapat berjalan sebagaimana mestinya. Guru hanya memberikan kesempatan kepada peserta didik untuk berdiskusi ketika guru memberikan pertanyaan yang perlu dijawab secara kelompok sehingga materi esensial yang seharusnya didiskusikan peserta didik tidak nampak.

Supervisi yang dilakukan terhadap guru yang melaksanakan pembelajaran dengan metode diskusi kelompok juga dilakukan di SMAN. 1 Sepauk terhadap guru NL pada tanggal 27 September 2017 jam pelajaran 6-7 di kelas X MIA 2. Dari hasil pengamatan yang dilakukan diskusi kelompok cukup berjalan baik karena nampaknya semua peserta didik bekerja sesuai dengan yang diminta oleh guru, namun pada saat mengemukan hasil pekerjaan hanya perwakilan kelompok yang nampaknya dapat berkomunikasi dengan baik sedangkan dari kelompok yang lain kurang aktif 
menanggapi hasil presentasi yang disampaikan. Selain itu guru juga kurang dapat mengarahkan dan memancing siswa untuk lebih aktif berdiskusi sehingga diskusi kelompok yang yang seharusnya berjalan dengan lancar lebih banyak didominasi oleh guru.

Berdasarkan data dan fakta yang telah dipaparkan ternyata pembinaan yang dilakukan oleh pengawas sekolah terhadap guru dalam melaksanakan pembelajaran belum mencapai kriteria minimal baik seperti yang telah diprogramkan, jika hal ini terus berlanjut maka akan berdampak pada kurang maksimalnya kinerja guru sehingga berakibat pada rendahnya mutu pembelajaran yang pada akhirnya akan menghasilkan mutu pendidikan yang rendah. Melihat kenyataan yang terjadi diatas penulis merasa perlu untuk melakukan penelitian tindakan dengan judul "Upaya Meningkatan Keterampilan Mengajar Guru Dalam Membimbing Diskusi Kelompok Kecil Melalui Pendekatan Kolaboratif Pada Sekolah Binaan Tahun Pelajaran 2017/2018"

Pelaksanaan supervisi akademik terhadap guru dalam melaksanakan pembelajaran di kelas dengan menggunakan pendekatan kolaboratif ini dipilih sebagai alternatif untuk meningkatkan keterampilan guru dalam membimbing diskusi kelompok kecil adalah karena pendekatan kolaboratif ini dipandang sesuai dengan kondisi guru-guru yang ada di sekolah binaan.

Berangkat dari rumusan masalah yang disampaikan diatas, maka tujuan penelitian ini adalah sebagai berikut: (1) untuk mengetahui bagaimanakah proses pelaksanaan pendekatan kolaboratif dalam upaya meningkatkan keterampilan mengajar guru dalam membimbing diskusi kelompok kecil; (2) untuk mengetahui apakah pendekatan kolaboratif dapat meningkatkan keterampilan mengajar guru dalam membimbing diskusi kelompok kecil.

Dalam mengajar seorang guru harus memiliki perilaku yang terampil sebagai modal awal dalam melaksanakan tugasnya, hal ini sejalan dengan pendapat Rusman (2014:80) yang menyatakan keterampilan dasar mengajar (teaching skills) pada dasarnya adalah berupa bentuk-bentuk perilaku bersifat mendasar dan khusus yang harus dimiliki oleh seorang guru sebagai modal awal untuk melaksanakan tugastugas pembelajarannya secara terencana dan profesional.

Ada beberapa jenis keterampilan mengajar yang harus dikuasai oleh guru agar dalam pelaksanaan tugas yang dilakukannya menjadi berkualitas. Menurut Turney dalam E. Mulyasa (2011:69) ada 8 keterampilan mengajar yang sangat berperan dalam menentukan kualitas suatu pembelajaran, yaitu keterampilan bertanya, memberi penguatan, mengadakan variasi, menjelaskan, membuka dan menutup pelajaran, membimbing diskusi kelompok kecil, mengelola kelas, serta mengajar kelompok kecil dan perorangan.

Keterampilan mengajar dalam membimbing diskusi kelompok kecil dapat dilakukan salah satunya adalah dengan menggunakan metode diskusi. Menurut Hamzah B. Uno \& Nurdin Mohammad (2015:99) metode diskusi adalah metode yang menghendaki agar siswa dan guru serta siswa dengan siswa lainnya terjadi interaksi dan saling tukar pengalaman dan informasi dalam memecahkan suatu masalah.

Dalam melaksanakan supervisi seorang pengawas sekolah dapat memilih pendekatan yang sesuai dengan karakter sekolah dan guru yang dihadapi. Menurut Glickman dalam Daryanto \& Tutik Rachmawati (2015:155) teori pendekatan supervisi ada tiga kelompok, yaitu pendekatan direktif, pendekatan non direktif dan pendekatan kolaboratif.

Menurut Piet A. Sahertian (2010:49) yang dimaksud dengan pendekatan kolaboratif adalah cara pendekatan yang memadukan cara pendekatan direktif dan non direktif menjadi cara pendekatan baru.

Setiap pendekatan supervisi memiliki tahaptahap dalam pelaksanaannya, begitu juga dengan pendekatan kolaboratif memiliki tahap-tahap dalam pelaksanaannya. Menurut Djam'an Satori (2016:82) tahap-tahap kegiatan pemberian supervisi dengan pendekatan kolaboratif adalah sebagai berikut: a) percakapan awal; Supervisor bertemu dengan guru atau sebaliknya, mereka membicarakan masalah yang dihadapi guru; b) observasi; Dalam percakapan awal supervisor berjanji akan mengobservasi kelas atau sebaliknya guru mengundang supervisor untuk mengadakan observasi kelas; c) analisis/ interpretasi; Dalam observasi digunakan alat pencatatan data. Data dianalisis dan ditafsirkan; d) percakapan akhir; Setelah data dianalisis lalu dibahas bersama dalam suatu percakapan; e) analisis akhir; Hasil percakapan yang dibahas disimpulkan untuk ditindaklanjuti; f) diskusi; Tahap terakhir diadakan diskusi.

\section{METODE PENELITIAN}

Jenis penelitian yang akan dilakukan adalah Penelitian Tindakan Sekolah, menurut Mulyasa (2012:9) Penelitian Tindakan Sekolah dapat diartikan sebagai sebuah upaya untuk memperbaiki kondisi dan memecahkan berbagai persoalan pendidikan yang dihadapi sekolah. Metode yang digunakan dalam penelitian adalah metode deskriftif. Menurut Whitney dalam $M$. Nazir (2014:63) metode deskriftif adalah pencarian fakta dengan interpretasi yang tepat. 
Penelitian ini dilaksanakan pada 3 (tiga) sekolah binaan yaitu SMAN. 2 Sintang, SMAN. 1 Sepauk dan SMA. Sinar Kasih Sintang. Banyaknya subyek tindakan dalam penelitian ini ada tiga orang guru matematika, yaitu masingmasing satu orang guru matematika di SMA. Negeri 2 Sintang, satu orang guru matematika SMA. Negeri 1 Sepauk, dan satu orang guru matematika di SMA Sinar Kasih Sintang.

Penelitan Tindakan Sekolah yang dilakukan ini memiliki tahapan pelaksanaan. Menurut Raka Joni dalam Agus Wasisto Dwi Doso Warso (2016:43) terdapat empat tahapan dalam Penelitian Tindakan Sekolah yaitu: pengembangan fokus masalah penelitian, perencanaan tindakan perbaikan, pelaksanaan tindakan perbaikan, observasi dan interpretasi, analisis dan refleksi.

Berdasarkan tahapan siklus dalam Penelitian Tindakan Sekolah, berikut ini merupakan deskripsi kegiatan yang akan dilakukan pada penelitian ini adalah:

Tahap perencanaan. kegiatan pada tahap ini yang dilakukan pengawas meliputi kegiatan : a) menyiapkan materi pendekatan kolaboratif yang akan didiskusikan dengan guru-guru; menetapkan skenario dan langkah-langkah pelaksanaan pendekatan kolaboratif yang berkaitan dengan perencanaan maupun pelaksanaannya, media dan alat bantu yang digunakan pada saat pelaksanaan kegiatan pendekatan kolaboratif, rumusan masalah yang akan diangkat dan akan dibicarakan tugas-tugas yang harus dikerjakan oleh guru-guru; c) menyiapkan instrumen observasi untuk mengukur keterampilan guru dalam membimbing diskusi kelompok kecil; d) menentukan jadwal berupa hari dan tanggal kegiatan siklus I, siklus II, dan lamanya diskusi untuk setiap siklus; e) membuat pedoman analisis data hasil observasi sebagai bahan untuk melakukan refleksi dan evaluasi; f) menentukan cara melakukan perbaikan jenis tindakan, rencana tindakan untuk siklus berikutnya.

Tahap pelaksanaan. kegiatan yang dilakukan pengawas pada tahap ini adalah melaksanakan supervisi dalam upaya meningkatan keterampilan mengajar guru dalam membimbing diskusi kelompok kecil dengan pendekatan kolaboratif sesuai langkah-langkah yang telah disepakati.

tahap pengamatan. pada tahap ini dilakukan observasi untuk melakukan penilaian mengenai keterampilan mengajar guru dalam membimbing diskusi kelompok kecil.

tahap refleksi. Pada tahap ini peneliti melakukan refleksi dengan melibatkan guru yang sudah diobservasi mengenai hasil pengamatan yang dilakukan selama kegiatan belajar mengajar.
Refleksi bertujuan untuk mengetahui kekurangan dan kelebihan yang terjadi saat kegiatan belajar mengajar berlangsung. Hasil refleksi yang dilakukan akan digunakan sebagai pertimbangan dalam merencanakan pelaksanaan kegiatan belajar mengajar dengan menggunakan motode diskusi kelompok untuk siklus berikutnya. Refleksi berkaitan dengan proses dan dampak tindakan perbaikan yang dilaksanakan dan kriteria dalam rencana tindakan siklus berikutnya.

Teknik pengumpul data yang digunakan dalam penelitian ini adalah observasi. Menurut Riduwan (2004:104) dalam http://makalahlaporanterbaru1.blogspot.co.id/201 3/05/pengertian-metode-observasi-definisi.html, observasi merupakan teknik pengumpulan data, dimana peneliti melakukan pengamatan secara langsung ke objek penelitian untuk melihat dari dekat kegiatan yang dilakukan.

Agar pengumpulan data dapat dilakukan secara efektif maka digunakan instrumen penelitian sebagai alat pengumpulan data. Menurut V. Wiratna Sujarweni (2014:76) instrumen penelitian adalah alat atau fasilitas yang digunakan peneliti dalam mengumpulkan data agar pekerjaannya lebih mudah dan hasilnya lebih baik, dalam arti lebih cermat, lengkap dan sistematis sehingga lebih mudah diolah. Pada penelitian ini alat pengumpul data yang digunakan adalah lembar pengamatan.

Lembar pengumpulan data ini digunakan untuk mengamati guru ketika melaksanakan kegiatan belajar mengajar sehingga dapat diketahui apakah sudah sesuai dengan prosedur yang telah direncanakan. Setelah data diperoleh maka data tersebut perlu dianalisa agar menjadi sesuatu yang dapat difahamai oleh berbagai fihak. Menurut Sugiyono (2008:89) analisis data adalah: "proses mencari dan menyusun secara sistematis data yang diperoleh dari hasil wawancara, catatan lapangan, dan dokumentasi, dengan cara mengorganisir data kedalam kategori, menjabarkan kedalam unit-unit, melakukan sintesa, menyusun kedalam pola, memilih mana yang penting dan yang akan dipelajari, dan membuat kesimpulan sehingga mudah difahami oleh diri sendiri maupun orang lain".

Data yang dianalisis ini berasal dari lembar pengamatan yang sudah dilakukan. Menurut Suharsimi Arikunto $(2010: 187)$ yang dimaksud dengan data dari lembar pengamatan adalah tampilan centangan yang terdapat dalam lembar pengamatan sesudah guru peneliti dan atau pengamat selesai melakukan pengamatan. Analisis data untuk lembar pengamatan yang digunakan pada penelitian ini dengan menggunakan empat pilihan yaitu dengan mencentang salah satu angka $1,2,3$, atau 4 , 
kemudian dihitung banyaknya centangan dalam masing-masing kolom.

Untuk mengukur kemampuan guru dalam membimbing diskusi kelompok kecil yakni dengan menghitung jumlah skor dibagi dengan skor maksimal dikali dengan $100 \%$. Menurut Kemdiknas (2011:167) rumus menghitung nilai akhir dari observasi kunjungan kelas adalah :

Nilai Akhir $=\frac{\text { Skor Perolehan }}{\text { Skor Maksimum }} \times 100 \%$

Penelitian ini dianggap berhasil jika nilai keterampilan mengajar guru dalam membimbing diskusi kelompok kecil mencapai rata-rata setiap siklus $\geq 75$. Nilai 75 diambil karena nilai 75 berada pada rentang kategori baik dari kinerja seorang guru dalam melaksanakan kegiatan belajar mengajar di kelas Kemdiknas (2011 :112).

\section{HASIL DAN PEMBAHASAN PENELITIAN Hasil Penelitian}

Penelitian Tindakan telah dilaksanakan di SMA. Negeri 2 Sintang pada tanggal 12 Maret dan 14 Maret 2018 untuk siklus I, tanggal 02 April dan 04 April 2018 untuk Siklus II. Di SMA. Negeri 1 Sepauk siklus I dilaksanakan pada tanggal 15 Maret dan 16 April 2018, siklus II dilaksanakan tanggal 23 April dan 25 April 2018 dan di SMA. Sinar Kasih Sintang siklus I dilaksanakan tanggal 20 April dan 21 April 2018, kemudian siklus II tanggal 27 April dan 28 April 2018.

\section{Deskripsi Hasil Penelitian Sikus I}

Penelitian di SMAN. 2 Sintang. Perencanaan siklus I adalah: a) mempersiapkan Rencana Penelitian Tindakan (RPT) yang merupakan langkah-langkah tindakan yang akan dilakukan terhadap guru; b) menetapkan indikator ketercapaian dan mempersiapkan instrumen penelitian yang terdiri dari lembar pengamatan dan daftar hadir kegiatan penelitian; c) menghubungi guru untuk menjelaskan aspekaspek yang akan diamati pada saat tindakan penelitian dan menyepakati tanggal pelaksanaan tindakan untuk siklus I.

Pelaksanaan tindakan siklusi I pertemuan 1 pada hari Senin tanggal 12 Maret 2018 dan siklus I pertemuan 2 hari Rabu tanggal 14 Maret 2018. Tindakan yang dilakukan peneliti adalah: a) mananyakan kepada guru apa yang menjadi kesulitan dalam memimpin diskusi kelompok; b) peneliti mengamati kegiatan pembelajaran didalam kelas untuk melihat sejauh mana keterampilan guru dalam memimpin diskusi kelompok; c) melakukan analisis data dan menginterpretasikannya; d) melakukan percakpan akhir dengan guru tentang hasil observasi pembelajaran; e) melaksanakan analisis akhir dengan guru tentang proses pembelajaran yang telah dilangsungkan; f) peneliti memberikan tanggapan-tanggapan dalam diskusi tentang hasil pembelajaran yang telah dilaksanakan sesuai dengan hasil analisis akhir yang telah dilakukan.

Pengamatan dilakukan dilakukan untuk mengetahui keterampilan guru dalam membimbing membimbing diskusi kelompok kecil pada saat proses pembelajaran berlangsung di kelas.

Refleksi dilakukan setelah semua aktifitas kegiatan penilaian dilaksanakan pada siklus I. Berdasarkan hasil proses tindakan yang telah dilakukan pada siklus I ternyata nilai rata-rata keterampilan mengajar guru dalam membimbing diskusi kelompok kecil di SMAN. 2 Sintang hanya mencapai $67 \%$ berarti belum mencapai target $75 \%$. Dari hasil refleksi yag dilakukan ditemui beberapa hal yang masih menjadi kelemahan yaitu: guru masih kurang mengajukan pertanyaan kepada seluruh anggota kelompok tentang pendapat setiap anggota, guru masih kurang dalam mengajukan pertanyaan kunci yang menantang, guru masih nampak belum mampu menghangatkan suasana dengan pertanyaan yang mengundang perbedaan pendapat, guru juga masih belum mampu memancing pendapat peserta yang kurang berpartisipasi, guru belum nampak memberikan kesempatan pertama kepada peserta didik yang kurang berpartisipasi, guru masih kurang mendorong peserta didik untuk mengomentari pendapat temannya.

Penelitian di SMAN. 1 Sepauk. Perencanaan siklus I adalah: a) mempersiapkan Rencana Penelitian Tindakan (RPT) yang merupakan langkah-langkah tindakan yang akan dilakukan terhadap guru; b) menetapkan indikator ketercapaian dan mempersiapkan instrumen penelitian yang terdiri dari lembar pengamatan dan daftar hadir kegiatan penelitian; c) menghubungi guru untuk menjelaskan aspekaspek yang akan diamati pada saat tindakan penelitian dan menyepakati tanggal pelaksanaan tindakan untuk siklus I.

Pelaksanaan tindakan siklusi I pertemuan 1 pada hari Kamis tanggal 15 Maret 2018 dan siklus I pertemuan 2 hari Senin 16 April 2018. Tindakan yang dilakukan peneliti adalah: a) mananyakan kepada guru apa yang menjadi kesulitan dalam memimpin diskusi kelompok; b) peneliti mengamati kegiatan pembelajaran didalam kelas untuk melihat sejauh mana keterampilan guru dalam memimpin diskusi kelompok; c) melakukan analisis data dan menginterpretasikannya; d) melakukan percakapan akhir dengan guru tentang hasil observasi pembelajaran; e) melaksanakan analisis akhir dengan guru tentang proses pembelajaran yang telah dilangsungkan; f) 
peneliti memberikan tanggapan-tanggapan dalam diskusi tentang hasil pembelajaran yang telah dilaksanakan sesuai dengan hasil analisis akhir yang telah dilakukan.

Pengamatan dilakukan dilakukan untuk mengetahui keterampilan guru dalam membimbing membimbing diskusi kelompok kecil pada saat proses pembelajaran berlangsung di kelas.

Refleksi dilakukan setelah semua aktifitas kegiatan penilaian dilaksanakan pada siklus I. Berdasarkan hasil proses tindakan yang telah dilakukan pada siklus I ternyata nilai rata-rata keterampilan mengajar guru dalam membimbing diskusi kelompok kecil di SMAN. 1 Sepauk hanya mencapai $68 \%$ berarti belum mencapai target $75 \%$.

Hasil refleksi terhadap keterampilan mengajar guru dalam membimbing diskusi kelompok kecil diperoleh beberapa kelemahan yaitu: belum menandai hal-hal yang tidak relevan dengan topik diskusi, belum nampak menguraikan setiap gagasan anggota kelompok, belum mengajukan pertanyaan kunci yang menantang, tidak memberikan kesempatan pertama kepada peserta didik yang kurang berpartisipasi, dan tidak menindak lanjuti hasil diskusi.

Penelitian di SMA. Sinar Kasih Sintang. Perencanaan siklus I adalah: a) mempersiapkan Rencana Penelitian Tindakan (RPT) yang merupakan langkah-langkah tindakan yang akan dilakukan terhadap guru; b) menetapkan indikator ketercapaian dan mempersiapkan instrumen penelitian yang terdiri dari lembar pengamatan dan daftar hadir kegiatan penelitian; c) menghubungi guru untuk menjelaskan aspekaspek yang akan diamati pada saat tindakan penelitian dan menyepakati tanggal pelaksanaan tindakan untuk siklus I.

Pelaksanaan tindakan siklusi I pertemuan 1 pada hari Jum'at 20 April 2018 dan siklus I pertemuan 2 hari Sabtu 21 April 2018. Tindakan yang dilakukan peneliti adalah: a) mananyakan kepada guru apa yang menjadi kesulitan dalam memimpin diskusi kelompok; b) peneliti mengamati kegiatan pembelajaran didalam kelas untuk melihat sejauh mana keterampilan guru dalam memimpin diskusi kelompok; c) melakukan analisis data dan menginterpretasikannya; melakukan percakapan akhir dengan guru tentang hasil observasi pembelajaran; e) melaksanakan analisis akhir dengan guru tentang proses pembelajaran yang telah dilangsungkan; f) peneliti memberikan tanggapan-tanggapan dalam diskusi tentang hasil pembelajaran yang telah dilaksanakan sesuai dengan hasil analisis akhir yang telah dilakukan.
Pengamatan dilakukan dilakukan untuk mengetahui keterampilan guru dalam membimbing membimbing diskusi kelompok kecil pada saat proses pembelajaran berlangsung di kelas.

Refleksi dilakukan setelah semua aktifitas kegiatan penilaian dilaksanakan pada siklus I. Berdasarkan hasil proses tindakan yang telah dilakukan pada siklus I ternyata nilai rata-rata keterampilan mengajar guru dalam membimbing diskusi kelompok kecil di SMA. Sinar Kasih Sintang hanya mencapai $72 \%$ berarti belum mencapai target $75 \%$.

Hasil refleksi terhadap keterampilan mengajar guru dalam membimbing diskusi kelompok kecil diperoleh beberapa kelemahan yaitu: guru belum sepenuhnya mampu menghangatkan suasana dengan pertanyaan yang mengundang perbedaan pendapat. Aspek lainnya yang masih menjadi kelemahan adalah guru belum sepenuhnya menindak lanjuti hasil diskusi yang telah dilakukakan peserta didik.

Secara keseluruhan nilai keterampilan mengajar guru dalam membimbing diskusi kelompok kecil pada siklus I dapat dilihat pada tabel dibawah ini:

\section{Tabel 2. Nilai Keterampilan Mengajar Guru Dalam Membimbing Diskusi Kelompok Kecil Siklus I}

\begin{tabular}{lccc} 
Guru Matematika & P1 & P2 & Rerata \\
\hline $\begin{array}{l}\text { SMAN. 2 } \\
\text { Sintang }\end{array}$ & $63 \%$ & $71 \%$ & $67 \%$ \\
\hline $\begin{array}{l}\text { SMAN. 1 } \\
\text { Sepauk }\end{array}$ & $61 \%$ & $74 \%$ & $68 \%$ \\
\hline $\begin{array}{l}\text { SMA. Sinar Kasih } \\
\text { Sing }\end{array}$ & $65 \%$ & $79 \%$ & $72 \%$
\end{tabular}

Sintang

Dari tabel diatas dapat dilihat bahwa keterampilan mengajar guru dalam membimbing diskusi kelompok kecil diketiga sekolah tersebut diatas mengalami kenaikan untuk setiap pertemuan.

Untuk guru matematika di SMA. Negeri 2 Sintang pada siklus I pertemuan 1 nilai yang diperoleh adalah 63 kemudian pada siklus I pertemuan 2 menjadi $71 \%$ terjadi kenaikan sebesar $8 \%$. Untuk guru matematika di SMA. Negeri 1 Sepauk pada siklus I pertemuan 1 nilai yang diperoleh adalah $61 \%$ kemudian pada siklus I pertemuan 2 menjadi 74\% terjadi kenaikan sebesar 13\% dan untuk guru matematika di SMA. Sinar Kasih Sintang pada siklus I pertemuan 1 nilai yang diperoleh adalah $65 \%$ kemudian pada siklus I pertemuan 2 menjadi $79 \%$ terjadi kenaikan sebesar $14 \%$.

\section{Deskripsi Hasil Penelitian Sikus II}

Penelitian di SMAN. 2 Sintang.

Perencanaan tindakan yang dilakukan pada siklus kedua adalah: a) menetapkan indikator yang akan 
menjadi fokus perbaikan yang masih nampak lemah pada saat pelaksanaan tindakan siklus I; b) menetapkan indikator-indikator yang perlu ditingkatkan dan dipertahankan karena pada siklus pertama sudah baik; c) mempersiapkan instrumen penelitian yang terdiri dari lembar pengamatan dan daftar hadir kegiatan penelitian; d) menghubungi guru untuk menjelaskan aspekaspek yang akan diamati pada saat tindakan penelitian dan menyepakati tanggal pelaksanaan tindakan untuk siklus II.

Pelaksanaan tindakan siklusi II pertemuan 1 pada hari Senin 02 April 2018 dan siklus II pertemuan 2 hari Rabu 02 April 2018. Tindakan yang dilakukan peneliti adalah: a) mananyakan kepada guru apa yang menjadi kesulitan dalam memimpin diskusi kelompok; b) peneliti mengamati kegiatan pembelajaran didalam kelas untuk melihat sejauh mana keterampilan guru dalam memimpin diskusi kelompok; c) melakukan analisis data dan menginterpretasikannya; d) melakukan percakapan akhir dengan guru tentang hasil observasi pembelajaran; e) melaksanakan analisis akhir dengan guru tentang proses pembelajaran yang telah dilangsungkan; f) peneliti memberikan tanggapan-tanggapan dalam diskusi tentang hasil pembelajaran yang telah dilaksanakan sesuai dengan hasil analisis akhir yang telah dilakukan.

Pengamatan dilakukan untuk mengetahui keterampilan guru dalam membimbing membimbing diskusi kelompok kecil, ternyata pada saat proses pembelajaran berlangsung di kelas semua aspek yang menjadi kelemahan pada siklus I sudah dapat diperbaiki. Refleksi dilakukan setelah semua aktifitas kegiatan penilaian dilaksanakan pada siklus II. Berdasarkan hasil proses tindakan yang telah dilakukan pada siklus II ternyata nilai rata-rata keterampilan mengajar guru dalam membimbing diskusi kelompok kecil di SMAN. 2 Sintang sudah mencapai $84 \%$ berarti melebihi target $75 \%$.

Penelitian di SMAN. 1 Sepauk. Perencanaan tindakan yang dilakukan pada siklus kedua adalah: a) menetapkan indikator yang akan menjadi fokus perbaikan yang masih nampak lemah pada saat pelaksanaan tindakan siklus I; b) menetapkan indikator-indikator yang perlu ditingkatkan dan dipertahankan karena pada siklus pertama sudah baik; c) mempersiapkan instrumen penelitian yang terdiri dari lembar pengamatan dan daftar hadir kegiatan penelitian; d) menghubungi guru untuk menjelaskan aspekaspek yang akan diamati pada saat tindakan penelitian dan menyepakati tanggal pelaksanaan tindakan untuk siklus II.

Pengamatan dilakukan untuk mengetahui keterampilan guru dalam membimbing membimbing diskusi kelompok kecil, ternyata pada saat proses pembelajaran berlangsung di kelas semua aspek yang menjadi kelemahan pada siklus I sudah dapat diperbaiki. Refleksi dilakukan setelah semua aktifitas kegiatan penilaian dilaksanakan pada siklus II. Berdasarkan hasil proses tindakan yang telah dilakukan pada siklus II ternyata nilai rata-rata keterampilan mengajar guru dalam membimbing diskusi kelompok kecil di SMAN. 1 Sepauk sudah mencapai $84 \%$ berarti melebihi target $75 \%$.

Penelitian di SMA. Sinar Kasih Sintang. Perencanaan tindakan yang dilakukan pada siklus kedua adalah: a) menetapkan indikator yang akan menjadi fokus perbaikan yang masih nampak lemah pada saat pelaksanaan tindakan siklus I; b) menetapkan indikator-indikator yang perlu ditingkatkan dan dipertahankan karena pada siklus pertama sudah baik; c) mempersiapkan instrumen penelitian yang terdiri dari lembar pengamatan dan daftar hadir kegiatan penelitian; d) menghubungi guru untuk menjelaskan aspekaspek yang akan diamati pada saat tindakan penelitian dan menyepakati tanggal pelaksanaan tindakan untuk siklus II.

Pelaksanaan tindakan siklusi II pertemuan 1 pada hari Jum'at 27 April 2018 dan siklus II pertemuan 2 hari Sabtu 28 April 2018. Tindakan yang dilakukan peneliti adalah: a) mananyakan kepada guru apa yang menjadi kesulitan dalam memimpin diskusi kelompok; b) peneliti mengamati kegiatan pembelajaran didalam kelas untuk melihat sejauh mana keterampilan guru dalam memimpin diskusi kelompok; c) melakukan analisis data dan menginterpretasikannya; d) melakukan percakapan akhir dengan guru tentang hasil observasi pembelajaran; e) melaksanakan analisis akhir dengan guru tentang proses pembelajaran yang telah dilangsungkan; $f$ ) peneliti memberikan tanggapan-tanggapan dalam diskusi tentang hasil pembelajaran yang telah dilaksanakan sesuai dengan hasil analisis akhir yang telah dilakukan.

Refleksi dilakukan setelah semua aktifitas kegiatan penilaian dilaksanakan pada siklus II. Berdasarkan hasil proses tindakan yang telah dilakukan pada siklus II ternyata nilai rata-rata keterampilan mengajar guru dalam membimbing diskusi kelompok kecil di SMA. Sinar Kasih Sintang sudah mencapai $87 \%$ berarti melebihi target $75 \%$.

Secara keseluruhan nilai keterampilan mengajar guru dalam membimbing diskusi kelompok kecil pada siklus II dapat dilihat pada tabel dibawah ini: 
Tabel 3. Nilai Keterampilan Mengajar Guru Dalam Membimbing Diskusi Kelompok Kecil Siklus II

\begin{tabular}{lccc}
\hline Guru Matematika & P1 & P2 & Rerata \\
\hline $\begin{array}{l}\text { SMAN. 2 } \\
\text { Sintang }\end{array}$ & $81 \%$ & $88 \%$ & $84 \%$ \\
\hline $\begin{array}{l}\text { SMAN. 1 } \\
\text { Sepauk }\end{array}$ & $79 \%$ & $89 \%$ & $84 \%$ \\
\hline $\begin{array}{l}\text { SMA. Sinar Kasih } \\
\text { Sintang }\end{array}$ & $85 \%$ & $89 \%$ & $87 \%$ \\
\hline
\end{tabular}

Untuk guru matematika di SMA. Negeri 2 Sintang pada siklus II pertemuan 1 nilai yang diperoleh $81 \%$ dan siklus II pertemuan 2 menjadi $88 \%$ terjadi kenaikan sebesar $7 \%$. Untuk guru matematika di SMA. Negeri 1 Sepauk pada siklus II pertemuan 1 nilai yang diperoleh $79 \%$ dan siklus II pertemuan 2 menjadi $89 \%$ terjadi kenaikan sebesar $10 \%$. Untuk guru matematika di SMA. Sinar Kasih Sintang Pada siklus II pertemuan 1 nilai yang diperoleh $85 \%$ dan siklus II pertemuan 2 menjadi $89 \%$ terjadi kenaikan sebesar $4 \%$.

Dari hasil yang didapat ternyata pada ketiga sekolah tersebut terjadi kenaikan nilai rata-rata untuk setiap siklus. Untuk lebih jelasnya dapat dilihat pada diagram dibawah ini:

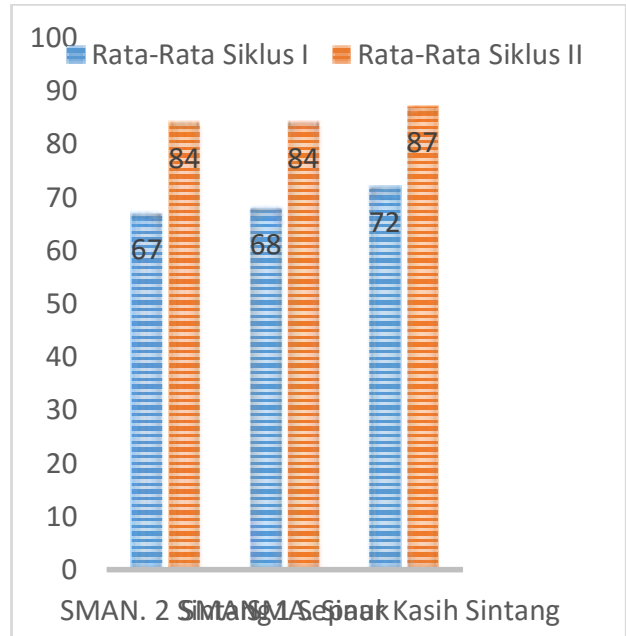

\section{Grafik 1. Nilai Keterampilan Mengajar Guru Dalam Membimbing Diskusi Kelompok Kecil}

Nilai rata-rata keterampilan mengajar guru dalam membimbing diskusi kelompok kecil di SMA. Negeri 2 Sintang pada siklus I sebesar 67\% dan rata- rata pada siklus II sebesar $84 \%$. Maka keterampilan mengajar guru dalam membimbing diskusi kelompok kecil di SMA. Negeri 2 Sintang dari siklus I ke siklus II mengalami peningkatan sebesar $17 \%$.
Nilai rata-rata keterampilan mengajar guru dalam membimbing diskusi kelompok kecil di SMA. Negeri 1 Sepauk pada siklus I sebesar $68 \%$ dan rata-rata pada siklus II sebesar $84 \%$. Maka keterampilan mengajar guru dalam membimbing diskusi kelompok kecil di SMAN. 1 Sepauk dari siklus I ke siklus II mengalami peningkatan sebesar $16 \%$.

Nilai rata-rata keterampilan mengajar guru dalam membimbing diskusi kelompok kecil di SMA. Sinar Kasih Sintang pada siklus I sebesar $72 \%$ dan rata-rata pada siklus II sebesar $87 \%$. Maka keterampilan mengajar guru dalam membimbing diskusi kelompok kecil di SMA. Sinar Kasih Sintang dari rata-rata siklus I ke siklus II mengalami peningkatan sebesar $15 \%$.

\section{Pembahasan Penelitian}

Penelitian tindakan sekolah ini ini bertujuan untuk meningkatan keterampilan mengajar guru dalam membimbing diskusi kelompok kecil melalui pendekatan kolaboratif pada sekolah binaan tahun pelajaran 2017/2018.

Dari hasil perhitungan yang telah dilakukan nilai rata-rata keterampilan mengajar guru matematika dalam membimbing diskusi kelompok kecil di SMA. Negeri 2 Sintang pada siklus I sebesar $67 \%$ (berada pada kriteria cukup) dan rata-rata pada siklus II sebesar $84 \%$ (berada pada kriteria baik) maka keterampilan mengajar guru matematika dalam membimbing diskusi kelompok kecil di SMA. Negeri 2 Sintang dari rata-rata siklus I ke siklus II mengalami peningkatan sebesar $17 \%$.

Terjadinya peningkatan ini karena adanya perbaikan keterampilan guru pada aspek-aspek seperti sudah jelas merumuskan tujuan diskusi, mampu merumuskan kembali masalah jika terjadi penyimpangan, menandai hal-hal yang tidak relevan dengan topik diskusi, merangkum hasil pembicaraan peserta diskusi, menguraikan kembali dan merangkum pendapat peserta, mengajukan pertanyaan kepada seluruh anggota kelompok tentang pendapat setiap anggota, menguraikan setiap gagasan anggota kelompok. Selain itu guru juga telah mampu mengajukan pertanyaan kunci yang menantang, dapat memberikan contoh secara tepat, mampu menghangatkan suasana dengan pertanyaan yang mengundang perbedaan pendapat, memberikan waktu berfikir yang cukup kepada peserta diskusi, mendengarkan dengan penuh perhatian setiap pendapat peserta didik, mampu memancing pendapat peserta yang kurang berpartisipasi, memberikan kesempatan pertama kepada peserta diskusi yang kurang berpartisipasi, dapat mencegah terjadinya monopoli pembicaraan, mendorong peserta didik untuk mengomentari pendapat temannya, meminta pendapat peserta 
didik ketika terjadi kebuntuan, merangkum hasil diskusi, menindak lanjuti hasil diskusi dan menilai proses diskusi yang telah dilakukan pada daftar penilaian.

Dari hasil perhitungan yang telah dilakukan nilai rata-rata keterampilan mengajar guru matematika dalam membimbing diskusi kelompok kecil di SMA. Negeri 1 Sepauk pada siklus I sebesar $68 \%$ (berada pada kriteria cukup) dan rata-rata pada siklus II sebesar $84 \%$ (berada pada kriteria baik) maka keterampilan mengajar guru matematika dalam membimbing diskusi kelompok kecil di SMA Negeri 1 Sepauk dari rata-rata siklus I ke siklus II mengalami peningkatan sebesar $16 \%$.

Terjadinya peningkatan ini karena adanya perbaikan keterampilan guru pada aspek-aspek seperti Menandai hal-hal yang tidak relevan dengan topik diskusi, Menguraikan setiap gagasan anggota kelompok, Mengajukan pertanyaan kunci yang menantang, Memberikan kesempatan pertama kepada yang kurang berpartisipasi dan Menindak lanjuti hasil diskusi.

Dari hasil perhitungan yang telah dilakukan nilai rata-rata keterampilan mengajar guru matematika dalam membimbing diskusi kelompok kecil di SMA. Sinar Kasih Sintang pada siklus I sebesar $72 \%$ (berada pada kriteria baik) dan ratarata pada siklus II sebesar $87 \%$ (berada pada kriteria sangat baik) maka keterampilan mengajar guru matematika dalam membimbing diskusi kelompok kecil di SMA. Sinar Kasih Sintang dari rata-rata siklus I ke siklus II mengalami peningkatan sebesar $15 \%$.

Terjadinya peningkatan ini karena adanya perbaikan keterampilan guru pada aspek-aspek seperti merumuskan tujuan diskusi dengan jelas, mengajukan pertanyaan kepada seluruh anggota kelompok tentang pendapat setiap anggota, mengajukan pertanyaan kunci yang menantang, menghangatkan suasana dengan pertanyaan yang mengundang perbedaan pendapat, dan menindak lanjuti hasil diskusi.

Tindakan yang telah dilakukan peneliti dengan melakukan supervisi model pendekatan kolaboratif untuk memperbaiki aspek-aspek yang masih menjadi kelemahan serta mempertahankan dan meningkatkan aspek-aspek yang sudah baik menjadi salah satu faktor yang dapat meningkatkan keterampilan guru dalam membimbing diskusi kelompok kecil, hal ini sesuai dengan pendapat Hariwung dalam Syaiful Sagala (2010:104) yang menyatakan bahwa tujuan supervisi pengajaran adalah membantu guru untuk bertumbuh dan berkembang dalam ruang lingkup mengajar dan kehidupan kelas, memperbaiki keterampilan mengajar dalam memperluas pengetahuan mereka serta menggunakan persiapan mereka.
Selain itu supervisi dengan model pendekatan kolaboratif yang dilakukan peneliti terhadap tiga orang guru matematika di SMAN. 2 Sintang, SMAN. 1 Sepauk dan SMA. Sinar Kasih Sintang berdampak terhadap meningkatnya keterampilan guru dalam membimbing diskusi kelompok kecil, hal ini terbukti dengan naiknya nilai rata-rata dari siklus I ke siklus II. Hal ini sejalan dengan pendapat Daryanto dan Tutik Rachmawati (2015:144) yang menyatakan bahwa tujuan supervisi pengajaran adalah untuk meningkatkan kepercayaan dan kemampuan serta keterampilan mengajar guru agar dapat melaksanakan tugas mengajar dengan baik.

Dari hasil penelitian yang telah dilakukan ternyata keterampilan mengajar guru dalam membimbing diskusi kelompok kecil dari pertemuan pertama sampai pertemuan terakhir menunjukan adanya perkembangan kearah yang lebih baik. Di SMAN. 2 Sintang siklus I pertemuan 1 nilainya 63 , siklus I pertemuan 2 nilainya 71, siklus II pertemuan 1 nilainya 81 dan siklus II pertemuan 2 nilainya 88. Di SMAN. 1 Sepauk siklus I pertemuan 1 nilainya 61, siklus I pertemuan 2 nilainya 74, siklus II pertemuan 1 nilainya 79 dan siklus II pertemuan 2 nilainya 89. Di SMA. Sinar Kasih Sintang siklus I pertemuan 1 nilainya 65 , siklus I pertemuan 2 nilainya 79 , siklus II pertemuan 1 nilainya 85 dan siklus II pertemuan 2 nilainya 89 .

Hal ini menunjukan bahwa supervisi dengan pendekatan kolaboratif telah dapat mendorong dan membantu guru untuk mengembangkan dan meningkatkan keterampilan mengajarnya, hal ini sejalan dengan pendapat Swearingen dalam Djam'an Satori (2016:64) yang menyatakan bahwa supervisi memberi dorongan dan stimulus dan membantu guru agar mengembangkan pengetahuan dan keterampilan mengajarnya.

\section{SIMPULAN DAN SARAN Simpulan}

Berdasarkan hasil penelitian tindakan sekolah yang telah dilaksanakan dalam Upaya Meningkatan Keterampilan Mengajar Guru Dalam Membimbing Diskusi Kelompok Kecil Melalui Pendekatan Kolaboratif Pada Sekolah Binaan Tahun Pelajaran 2017/2018 dapat disampaikan beberapa simpulan hasil penelitian sebagai berikut: (1) proses pelaksanaan penelitian tindakan sekolah dengan pendekatan kolaboratif dilakukan melalui 6 tahap yaitu: percakapan awal, observasi, analisis/ interpretasi, percakapan akhir, analisis akhir, dan diskusi; (2) pendekatan kolaboratif dapat meningkatkan keterampilan mengajar guru dalam membimbing diskusi kelompok kecil. Hal ini dapat dilihat dari hasil penilaian rata-rata setiap siklus, guru matematika SMAN. 2 Sintang mengalami peningkatan $17 \%$ 
dari siklus I ke siklus II, guru matematika SMAN. 1 Sepauk mengalami peningkatan $16 \%$ dari siklus I ke siklus II dan guru matematika di SMA. Sinar Kasih Sintang mengalami peningkatan $15 \%$ dari siklus I ke siklus II.

\section{Saran}

Mengingat pentingnya keterampilan mengajar yang harus dimiliki guru dalam membimbing diskusi kelompok kecil, maka ada beberapa saran yang perlu penulis sampaikan. Saran-saran tersebut adalah: (1) Disarankan kepada pengawas sekolah agar menggunakan pendekatan kolaboratif untuk meningkatkan keterampilan mengajar guru dalam membimbing diskusi kelompok kecil di sekolah binaan masingmasing; (2) Dalam meningkatkan keterampilan mengajar guru dalam membimbing diskusi kelompok kecil Kepala sekolah hendaknya menggunakan pendekatan kolaboratif; (3) Dalam mengajar dengan menggunakan metode diskusi kelompok sebaiknya memahami aspek-aspek keterampilan mengajar dalam membimbing diskusi kelompok kecil agar proses diskusi dapat berjalan lancar.

\section{DAFTAR PUSTAKA}

Agus Wasisto Dwi Doso Warso. 2016. Penelitian Tindakan Kepengawasan dan Tindakan Sekolah. Yogyakarta: Pustaka Pelajar.

Daryanto \& Tutik Rachmawati. 2015. Supervisi Pembelajaran. Yogyakarta: Gava Media

Djam'an Satori. 2016. Pengawasan dan Penjaminan Mutu Pendidikan. Bandung: Alfabeta.

E. Mulyasa. 2011. Menjadi Guru Profesional Menciptakan Pembelajaran Kreatif dan Menyenangkan. Bandung: P.T. Remaja Rosda Karya.

2012. Penelitian Tindakan Sekolah Meningkatkan Produktivitas Sekolah. Bandung: PT. Remaja Rosdakarya.
Hamzah B. Uno \& Nurdin Mohammad. Belajar Dengan Pendekatan PAIKEM. Jakarta: PT. Bumi Aksara

Kemdiknas. 2007. Standar Kualifikasi Akademik \& Kompetensi Guru. Jakarta: Mendiknas.

Kemdiknas. 2011. Buku Kerja Pengawas Sekolah. Jakarta: P2TK Badan Pengembangan SDM Kemdiknas.

Kemdikbud. 2016. Permendikbud Nomor 22 Tentang Standar Proses. Jakarta: Mendikbud.

Kusnadi. 2008. Strategi Pembelajaran Ilmu Pengetahuan. Pekan Baru: Yayasan Pusaka Riau.

M. Nazir. 2014. Metode Penelitian. Bogor: Ghalia Indonesia.

Pemerintah RI. 2005. Undang-Undang RI Nomor 19 Tentang Standar Nasional Pendidikan. Jakarta: Presiden RI

Piet A. Sahertian. 2010. Konsep Dasar \& Teknik Supervisi Pendidikan Dalam Rangka Pengembangan Sumber Daya Manusia. Jakarta: PT. Rineka Cipta.

Riduwan. 2004. Pengertian Metode Observasi Definisi Menurut Para Ahli Dalam Penelitian.

http://makalahlaporanterbaru1.blogspot.co.id/ 2013/05/pengertian-metode-observasi-

definisi.html. Diakses tanggal 14 Juli 2017.

Rusman. 2014. Model-Model Pembelajaran Mengembangkan Profesionalisme Guru. Depok: PT. Rajagrafindo Persada.

Sugiyono. 2008. Memahami Penelitian Kualitatif. Bandung: CV. Alfabeta.

Suharsimi Arikunto. 2010. Penelitian Tindakan Untuk Guru, Kepala Sekolah \& Pengawas. Yogyakarta: Aditya Media.

Syaiful Sagala. 2010. Supervisi Pembelajaran. Bandung: CV. Alfabeta

V. Wiratna Sujarweni. 2014. Metodologi Penelitian. Yogyakarta: Pustakabaru Press. 